\title{
Relationship between injury severity, random blood glucose and management outcome in a cohort of Nigerian patients with head injury
}

\author{
Augustine A Adeolu ${ }^{1,2}$, TB Rabiu' ${ }^{1}$, OI Orhorhoro' ${ }^{1}$, AO Malomo ${ }^{1,2}$, MT Shokunbi ${ }^{1,2}$ \\ ${ }^{1}$ Department of Neurological Surgery, University College Hospital, ${ }^{2}$ Department of Surgery, College of Medicine, University of Ibadan, Ibadan, \\ Nigeria
}

\begin{abstract}
Objective: This study was designed to evaluate the relationship between injury severity, admission Random Blood Glucose [RBG] and management outcome in a cohort of Nigerian patients with Head Injury [HI]. Materials and Methods: RBG was determined at admission, twenty four hours as well as seventy two hours after admission in patients with head injury. Severity of injury was graded using Glasgow Coma Scale (GCS). Outcome of management was determined by Glasgow Outcome Score at discharge. Serum glucose level of $\geq 11.1 \mathrm{mmol} / \mathrm{l}$ was taken as hyperglycaemia. Analyses of variance [ANOVA] was used to determine level of significance and a $P$ value of $<0.05$ was considered significant. Results: There were 146 male and 30 female patients (range: 2 years to 78 years; mean; 34.4 years, SD: 16.4 years). Most (36.4\%) of the patients had severe HI. Only $2.5 \%$ of the patients had hyperglycaemia at admission. Death occurred in $25 \%$ of the patients, moderate disability occurred in $30.1 \%$ and good outcome occurred in $35.8 \%$. Hyperglycaemia occurred in one patient each in mild and severe head injuries and in two patients with moderate head injury. All the patients with hyperglycaemia had favourable outcome. Conclusion: Random blood glucose of $\geq 11.1 \mathrm{mmol} / \mathrm{l}$ was not common at admission in head injured patients in this cohort of patients and the value was not associated with severe injury or poor outcome.
\end{abstract}

Key words: Head injury, hyperglycaemia, outcome, severity

\section{Introduction}

Stress, including trauma, is often associated with changes in whole body nutrient metabolism which may complicate clinical management and compromise survival. ${ }^{[1,2]}$ These changes include elevation in plasma glucose, lactate, non-esterified fatty acids, cortisol, glucagon, insulin and catecholamines. ${ }^{[3,4]}$ Hadfield et al . showed that the metabolic changes occurring after head injury is similar to those occurring in extra-cranial injuries. ${ }^{[4]}$ They also observed that plasma catecholamines were higher in the head injured patients initially and at about seven days after injury compared to patients

\begin{tabular}{|l|l|}
\hline \multicolumn{2}{|c|}{ Access this article online } \\
\hline Quick Response Code: & Website: \\
\hline & www.ruralneuropractice.com \\
\cline { 2 - 3 } & \\
\hline & DOI: \\
\hline
\end{tabular}

with extra-cranial injuries. The hyperglycaemia results from an increase in circulating catecholamines due to hypothalamic - adrenal activation and elevation of other diabetogenic hormones. ${ }^{[4,5]}$ The hyperglycaemia has also been suggested to be transient and it is associated with severe head injury and poorer neurological outcome. ${ }^{[6-11]}$ The reasons for the poorer neurological outcome is not well understood but several investigators have postulated that brain injury is aggravated by elevated glucose levels because of enhanced anaerobic glycolysis and lactic acidosis in ischaemic conditions. ${ }^{[12,13]}$ There is no consensus value of Random Blood Glucose (RBG) that has been associated with poor outcome following acute traumatic brain injury; hence, there is no formal recommended target glucose range for hyperglycemic control in patients with traumatic brain injury. However, most studies have used the $11.1 \mathrm{mmol} / \mathrm{l}$ as the critical cut off point for hyperglycaemia.

In a recent study from a small cohort of Nigerian patients with head injury, hyperglycaemia was found

Address for correspondence:

Dr. Augustine A Adeolu, Department of Neurological Surgery, University College Hospital, PO Bo × 40476, Dugbe, Ibadan, Nigeria.

E-mail: adeoluaa@yahoo.com 
only in a small number of patients unlike the findings in other parts of the world. ${ }^{[14]}$ The small sample size and this unique finding call for further investigation in the work. Furthermore, this seems to be the only study on the subject in a predominantly black population. The serum levels of the hormones responsible for the metabolic changes in stress is yet to be determined in the same population; most of the available studies were done in predominantly white population. Also, there are no reports on racial differences in metabolic response to trauma.

This study was thus designed to evaluate the relationship between injury severity, admission Random Blood Glucose [RBG] and management outcome in a larger cohort of Nigerian patients with Head Injury [HI].

\section{Materials and Methods}

All patients who presented to our Accident and Emergency department with HI over a one year period were included in the study. We obtained serial RBG from the patients as part of our routine protocol for the management of patients with head injury. Venous blood sample was collected to determine glucose levels in the hospital central laboratory using oxidase method within thirty minutes to one hour of obtaining the blood sample. We determined the RBG at admission, 24 hours and 72 hours after admission. We defined four categories of RBG: $<3.5 \mathrm{mmol} / \mathrm{l}, 3.5$ to $6.1 \mathrm{mmol} / \mathrm{l}$, $6.2-11.1 \mathrm{mmol} / \mathrm{l}$ and $>11.1 \mathrm{mmol} / \mathrm{l}$. Further grouping into $<3.8 \mathrm{mmol} / \mathrm{l}, 3.8$ to $<7.8 \mathrm{mmol} / \mathrm{l}, 7.8$ to $11.1 \mathrm{mmol} / 1$ and $>11.1 \mathrm{mmol} / \mathrm{l}$ was also performed. In addition, we obtained data on demographics, time from injury to presentation at the hospital, other inter-current illnesses, treatment with glucose containing-fluid prior to presentation at our center, diagnosis, head injury severity, surgical intervention and treatment outcome. The severity of head injury (brain injury) was graded using the Glasgow Coma Scale (GCS) into mild (13-15), moderate (9-12) and severe (3-8). Outcome of management was determined by Glasgow Outcome Score at the time of discharge from the hospital.

We used a one-way analysis of variance (ANOVA) to determine the statistical significance of the relationship between admission RBG and head injury severity as well as admission RBG and outcome. The level of significance was taken as $P<0.05$. We also analysed a subset of patients who presented to us within twenty four hours of their injuries.

\section{Results}

One hundred and seventy six patients were included in the study. The age range was 2 years to 78 years [mean age: 34 years, standard deviation of 16.4 years]. Sixty eight per cent of the patients were between 18 years and 50 years of age. Severe head injury constituted the largest group $(64 ; 36.4 \%)$, followed by moderate head injury (58; $33.0 \%)$ and mild head injury $(54 ; 30.6 \%)$.

One hundred and sixty three patients in whom we were able to perform RBS on admission were further analysed. Most (97.4\%) of these patients had RBS below $11.1 \mathrm{mmol} / 1$ and only four patients (2.6\%) had 11.1 $\mathrm{mmol} / \mathrm{l}$ and above [Table 1]. Only two patients (1.2\%) had hypoglycaemia. The relationship between admission glucose range and severity of head injury using the Glasgow coma score is shown in Table 1. The four patients with hyperglycaemia were distributed across the three groups of head injury with no obvious pattern or relationship with the severity of injury. The same also goes for the other glucose ranges. One way ANOVA shows no statistical significance between the admission RBG and severity of head injury $(P=0.625)$.

About $66.3 \%$ of the patients had favourable (moderate disability and good outcome) outcome with death occurring in $25 \%$ and poor outcome (death, persistent vegetable state and severe disability) in about $33.7 \%$. This is further depicted in Table 2.

Table 1: Relationship between admission glucose range and severity of head injury in nigerian africans as assessed using the glasgow coma scale score

\begin{tabular}{lcccc}
\hline Admission & \multicolumn{3}{c}{ Head injury severity } & \multirow{2}{*}{$\begin{array}{c}\text { Total } \\
\text { RBG }\end{array}$} \\
\cline { 2 - 4 } & $\begin{array}{c}\text { Mild } \\
\text { (GCS 13-15) }\end{array}$ & $\begin{array}{c}\text { Moderate } \\
\text { (GCS 9-12) }\end{array}$ & $\begin{array}{c}\text { Severe } \\
\text { (GCS 3-8) }\end{array}$ & \\
\hline$<3.5 \mathrm{mmol} / \mathrm{L}$ & 1 & 1 & 0 & $2(1.2)$ \\
$3.5-6.1 \mathrm{mmol} / \mathrm{L}$ & 24 & 27 & 23 & $74(45.4)$ \\
$6.2-11 \mathrm{mmol} / \mathrm{L}$ & 25 & 24 & 34 & $83(50.9)$ \\
$>11.1 \mathrm{mmol} / \mathrm{L}$ & 1 & 2 & 1 & $4(2.5)$ \\
Total & 51 & 54 & 58 & $163(100)$ \\
\hline
\end{tabular}

RBG=Random blood glucose, GCS=Glasgow coma scale

Table 2: Management outcome of head injury among the 175 nigerian africans with head injury using the Glasgow outcome scale scores

\begin{tabular}{lcc}
\hline Outcome & Frequency & Percentage \\
\hline Death & 44 & 25.1 \\
Persistent vegetative state & 1 & 0.6 \\
Severe disability & 14 & 8.0 \\
Moderate disability & 53 & 30.3 \\
Good outcome & 63 & 36.0 \\
Total & 175 & 100.0 \\
\hline
\end{tabular}


Table 3 shows the relationship between injury severity and outcome of management: More deaths (80\%) occurred in patients with severe injury and good outcome was more $(60.3 \%)$ in patients with mild head injury. However, such relationship was not observed between RBG on admission and outcome of management [Table 4]: None of the patients with hyperglycaemia died and three out of them had good outcome and the remaining one had moderate disability $(P=0.461)$.

Further analysis of one hundred patients who presented within twenty four hours of injury was performed. The relationship between RBG, injury severity and outcome of management demonstrated the same pattern as above. These findings are depicted in Table 5. The RBG of these patients was further regrouped as shown in Tables 6 and 7. Majority (78\%) had values below $7.9 \mathrm{mmo} / \mathrm{l}$. However, out of the eighteen patients with RBG of 7.8-11.1 mmol/1, 50\% (9 patients) had severe injury and only two patients had mild head injury. This pattern was not observed in the same subgroup when RBG was compared to management outcome with $72.2 \%$ of the eighteen patients having favourable outcome (moderate disability and good outcome).

We also performed further analysis using a lower threshold for the hyperglycaemia $(8.9 \mathrm{mmol} / \mathrm{l})$. Majority of the patients still had RBG below this level with no significant relationship between those who had RBG above the critical levels and injury severity and management outcome.

Table 3: Relationship between injury severity and management outcome in Nigerian Africans with head injury

\begin{tabular}{lcccccc}
\hline $\begin{array}{l}\text { Injury } \\
\text { severity }\end{array}$ & \multicolumn{5}{c}{ Management outcome } & Total \\
\cline { 2 - 6 } & $\begin{array}{c}\text { Death } \\
\text { Persistent } \\
\text { vegetative } \\
\text { state }\end{array}$ & $\begin{array}{c}\text { Severe } \\
\text { disability }\end{array}$ & $\begin{array}{c}\text { Moderate } \\
\text { disability }\end{array}$ & $\begin{array}{c}\text { Good } \\
\text { outcome }\end{array}$ & \\
\hline Mild & 4 & 0 & 0 & 12 & 38 & 54 \\
Moderate & 5 & 0 & 5 & 26 & 22 & 58 \\
Severe & 35 & 1 & 9 & 15 & 3 & 63 \\
Total & 44 & 1 & 14 & 53 & 63 & 175 \\
\hline
\end{tabular}

\section{Discussion}

The sample size of one hundred and seventy six patients is much higher compared to that of fifty patients in an earlier study by Adeolu et al. working in another institution in Nigeria. ${ }^{[14]}$ This latter study, is perhaps, the only one on the subject in this part of the world. There was predominance of male and young patients in our study group in line with other epidemiological studies on trauma including head injury. ${ }^{[15-18]}$

The admission random plasma glucose was mostly below $11.1 \mathrm{mmol} / \mathrm{l}$ as found in $89.4 \%$ of all the patients and in $98.3 \%$ of the patients with severe head injuries. There was no statistical significance between admission RBG and injury severity as well as between admission RBG and outcome at discharge. These findings were similar to the previous Nigerian study but at variance with studies from other parts of the world. ${ }^{[14]}$ Lam et al. and other workers have demonstrated a direct relationship between admission plasma blood glucose and the severity of head injury and a worse outcome in patients with hyperglycaemia. ${ }^{[7-11]}$ Liu-DeRyke et al. demonstrated that peak random blood sugar within the first twenty four hours of injury and admission has the best prognostic value in predicting outcome. ${ }^{[6]}$ Evidence from the literature also suggests that hyperglycaemia following acute traumatic brain injury is transient. ${ }^{[6]}$ Could the delay in presentation account for these differences? In the previous study in Ile-Ife, Nigeria, late presentation of the patients could not be ruled out. Some studies suggested that the elevated glucose may be transient and the values could be within normal limit if the patient presents after twenty four hours. The argument against this includes the demonstration of elevated RBS values up to three days after the injury. ${ }^{[3,9]}$ In addition, in order to overcome this short coming, a subset of one hundred patients who presented within twenty four hours were analysed [Tables 5-7]. The findings were not different from the aforementioned.

In the additional analysis using different grouping of RBG [Tables 6 and 7], though majority of the

Table 4: Relationship between admission random plasma glucose and management outcome in nigerian africans with head injury

\begin{tabular}{|c|c|c|c|c|c|c|}
\hline \multirow{2}{*}{$\begin{array}{l}\text { Admission } \\
\text { RPG }\end{array}$} & \multicolumn{5}{|c|}{ Management outcome } & \multirow[t]{2}{*}{ Total (\%) } \\
\hline & Death & $\begin{array}{c}\text { Persistent } \\
\text { vegetative state }\end{array}$ & $\begin{array}{c}\text { Severe } \\
\text { disability }\end{array}$ & $\begin{array}{l}\text { Moderate } \\
\text { disability }\end{array}$ & $\begin{array}{c}\text { Good } \\
\text { outcome }\end{array}$ & \\
\hline$<3.5 \mathrm{mmol} / \mathrm{l}$ & 1 & 0 & 0 & 1 & 0 & $2(1.2)$ \\
\hline $3.5-6.1 \mathrm{mmol} / \mathrm{l}$ & 16 & 0 & 7 & 21 & 30 & $74(45.7)$ \\
\hline $6.2-11.1 \mathrm{mmol} / \mathrm{l}$ & 23 & 1 & 5 & 24 & 29 & $82(50.6)$ \\
\hline$>11.1 \mathrm{mmol} / \mathrm{l}$ & 0 & 0 & 0 & 1 & 3 & $4(2.5)$ \\
\hline Total (\%) & $40(24.7)$ & $1(0.6)$ & $12(7.4)$ & $47(29.0)$ & $62(38.3)$ & 162 \\
\hline
\end{tabular}


patients still had values below $7.8 \mathrm{mmo} / \mathrm{l}$, about $50 \%$ of the patients with 7.8-11.1 $\mathrm{mmo} / \mathrm{L}$ RBG range had severe injury. There was no such relationship within this subgroup when management outcome was considered [Table 6]. The number of this subset was small (18 patients), thus limiting the conclusion from the finding but it suggests that the critical level for hyperglycaemia in severe injury in our population may be lower compared to other parts of the world. This assertion will need to be verified in larger population focusing on this subset of patients.

We used the central laboratory of the hospital for the glucose analysis to ensure standard and uniformity. The laboratory performs most plasma glucose analysis in the hospital including in patients with diabetes mellitus. It is thus, unlikely that technical issues were responsible for the findings in the two studies which are largely at variance with findings from other part of the world.

Within group analysis in some of the previous studies also showed direct relationship between the Glasgow coma score and glucose levels especially in subgroup of patients with severe head injury. ${ }^{[17]}$ Also patients with other injuries tend to have higher glucose levels compared to those with solely head injuries. Since most of the patients had serum glucose levels below the threshold for hyperglycaemia (both $8.9 \mathrm{mmol} / \mathrm{L}$ and $11.1 \mathrm{mmol} / \mathrm{L}$ ) in the current study, these factors do not seem to have significant influence on the glucose levels

Table 5: Relationship between admission glucose range and severity of head injury in nigerian africans presenting within 24 hours of their injuries

\begin{tabular}{|c|c|c|c|c|}
\hline \multirow{2}{*}{$\begin{array}{l}\text { Admission } \\
\text { RBG }\end{array}$} & \multicolumn{3}{|c|}{ Head injury severity } & \multirow[t]{2}{*}{ Total } \\
\hline & $\begin{array}{c}\text { Mild } \\
\text { (GCS 13-15) }\end{array}$ & $\begin{array}{c}\text { Moderate } \\
\text { (GCS 9-12) }\end{array}$ & $\begin{array}{c}\text { Severe } \\
\text { (GCS 3-8) }\end{array}$ & \\
\hline$<3.5 \mathrm{mmol} / \mathrm{L}$ & 0 & 1 & 0 & 1 \\
\hline 3.5-6.1 mmol/L & 12 & 14 & 13 & 39 \\
\hline $6.2-11 \mathrm{immol} / \mathrm{L}$ & 13 & 13 & 28 & 54 \\
\hline$>11.1 \mathrm{mmol} / \mathrm{L}$ & 1 & 1 & 1 & 3 \\
\hline Total & 26 & 29 & 42 & 97 \\
\hline
\end{tabular}

compared to the previous reports and further analysis for their effects was not necessary.

A very remote explanation for the findings in this study is the possibility of wrong diagnosis.

This is very unlikely. In the first instance, all the patients recruited for the study were evaluated by at least a senior resident in neurosurgery and most were evaluated by a consultant neurosurgeon. Also, only few of the patients had hyperglycaemia and these were not related to injury severity and thus, issue of misdiagnosis, if it ever occurred, would not have any effect on the findings. Moreover, there was strong correlation between injury severity and management outcome [Table 3]: Most patients (80\%) who died had severe head injury and most patients $(60 \%)$ with good outcome had mild head injury. These findings are in keeping with results from other parts of the world and confirm that the diagnoses were quite accurate.

The low incidence of hyperglycaemia in this study will suggest normal, or even low serum cortisol. The latter will be at variance with findings in previous studies and will indicate probable higher incidence of pituitary dysfunction in head injured patients in the study population. These assertions will need to be confirmed in future studies.

Though plausible, the current trend to avoid glucose containing intravenous fluid in head injury patients should be applied with caution in Nigerian Africans with head injury in view of the findings in this study. If such intravenous fluids are used, the blood glucose should be monitored regularly to detect hypoglycaemia since most of the patients may have been euglycaemic.

\section{Conclusion}

Our findings suggest that metabolic response, and specifically glucose metabolism, in head injured patients in the study population is different compared to findings from other parts of the world. Further studies in other

Table 6: Further analysis of relationship between admission random plasma glucose and management outcome in nigerian africans with head injury presenting within 24 hours of injury

\begin{tabular}{lcccccc}
\hline Admission & \multicolumn{4}{c}{ Management outcome } & Total (\%) \\
\cline { 2 - 6 } & Death & $\begin{array}{c}\text { Persistent } \\
\text { vegetative state }\end{array}$ & $\begin{array}{c}\text { Severe } \\
\text { disability }\end{array}$ & $\begin{array}{c}\text { Moderate } \\
\text { disability }\end{array}$ & $\begin{array}{c}\text { Good } \\
\text { outcome }\end{array}$ \\
\hline$<3.8 \mathrm{mmol} / \mathrm{l}$ & 0 & 0 & 0 & 1 & 1 & $2(2.0)$ \\
$3.8-7.81 \mathrm{mmol} / \mathrm{l}$ & 23 & 1 & 7 & 19 & 26 & $76(76.8$ \\
$7.8-11.1 \mathrm{mmol} / /$ & 4 & 0 & 1 & 7 & 6 & $18(18.2)$ \\
$>11.1 \mathrm{mmol} / \mathrm{l}$ & 0 & 0 & 0 & 28 & $3(3.0)$ \\
Total $(\%)$ & 27 & 1 & 8 & 28 & $35(100)$ \\
\hline
\end{tabular}

RPG=??? 
Table 7: Further analysis of relationship between admission random plasma glucose and injury severity in nigerian africans with head injury presenting within 24 hours of injury

\begin{tabular}{lcccc}
\hline Admission & \multicolumn{3}{c}{ Head injury severity } & Total \\
\cline { 2 - 4 } & $\begin{array}{c}\text { Mild } \\
\text { RBG }\end{array}$ & $\begin{array}{c}\text { Moderate } \\
\text { (GCS 13-15) }\end{array}$ & $\begin{array}{c}\text { Severe } \\
\text { (GCS 9-12) }\end{array}$ & \\
\hline$<3.8 \mathrm{mmol} / \mathrm{l}$ & 0 & 2 & 0 & 2 \\
$3.8-7.81 \mathrm{mmol} / \mathrm{l}$ & 24 & 20 & 33 & 77 \\
$7.8-11.1 \mathrm{mmol} / \mathrm{l}$ & 2 & 7 & 9 & 18 \\
$>11.1 \mathrm{mmol} / \mathrm{l}$ & 1 & 1 & 1 & 3 \\
Total $(\%)$ & 27 & 30 & 43 & 100 \\
\hline
\end{tabular}

GCS=Glasgow coma scale, RBG= Random blood glucose

parts of the sub-Saharan Africa, especially with higher study population, are needed to ascertain the findings in this study.

\section{Acknowledgement}

The authors thank Drs. M.A. Kuti and D. Dairo of the Department of Chemical Pathology and Department of Epidemiology and Statistics, University of Ibadan, Ibadan respectively for their advice and encouragement.

\section{References}

1. Frayn KN. Hormonal control of metabolism in trauma and sepsis. Clin Endocrinol (Oxf) 1986;24:577-99.

2. Long CL, Schaffel N, Geiger JW, Schiller WR, Blakemore WS. Metabolic response to injury and illness: Estimation of energy and protein needs from indirect calorimetry and nitrogen balance. JPEN J Parenter Enteral Nutr 1979;3:452-6.

3. Chioléro R, Schutz Y, Lemarchand T, Felber JP, de Tribolet N, Freeman J, et al. Hormonal and metabolic changes following severe head injury or noncranial injury. JPEN J Parenter Enteral Nutr 1989;13:5-12.

4. Hadfield JM, Little RA, Jones RA. Measured energy expenditure and plasma substrate and hormonal changes after severe head injury. Injury 1992;23:177-82.
5. Clifton GL, Ziegler MG, Grossman RG. Circulating catecholamines and sympathetic activity after head injury. Neurosurgery 1981;8:10-4.

6. Liu-DeRyke X, Collingridge DS, Orme J, Roller D, Zurasky J, Rhoney DH. Clinical impact of early hyperglycemia during acute phase of traumatic brain injury. Neurocrit Care 2009;11:151-7.

7. Jeremitsky E, Omert LA, Dunham CM, Wilberger J, Rodriguez A. The impact of hyperglycemia on patients with severe brain injury. J Trauma 2005;58:47-50.

8. Lam AM, Winn HR, Cullen BF, Sundling M. Hyperglycemia and neurological outcome in patients with head injury. J Neurosurg 1999;75:545-51.

9. Margulies DR, Hiatt JR, Vinson D Jr, Shabot MM. Relationship of hyperglycemia and severity of illness to neurologic outcome in head injury patients. Am Surg 1994;60:387-90.

10. Michaud LJ, Rivara FP, Longstreth WT Jr, Grady MS. Elevated initial blood glucose levels and poor outcome following severe brain injuries in children. J Trauma 1991;31:1356-62.

11. Rovlias A, Kotsou S. The influence of hyperglycemia on neurological outcome in patients with severe head injury. Neurosurgery 2000;46:335-43.

12. Kraig RP, Petito CK, Plum F, Pulsinelli WA. Hydrogen ions kill brain at concentrations reached in ischemia. J Cereb Blood Flow Metab 1987;7:379-86.

13. Marsh WR, Anderson RE, Sundt TM Jr. Effect of hyperglycemia on brain $\mathrm{pH}$ levels in areas of focal incomplete cerebral ischemia in monkeys. J Neurosurg 1986;65:693-6.

14. Adeolu AA, Komolafe EO, Abiona TC, Tomi-Olugbodi AO, Adegoke OA. Plasma glucose level in Nigerian Africans with head injury. J Clin Neurosci 2010;17:325-7.

15. Adeloye A, Ssembatya-Lule GC. Aetiological and epidemiological aspects of acute head injury in Malawi. East Afr Med J 1997;74:822-8.

16. Adeolu AA, Malomo AO, Shokunbi MT, Komolafe EO, Abiona TC Etiology of head injuries in Southwestern Nigeria: A public health perspective. Internet J Epidemiol 2004;2.

17. Akang EE, Kuti MA, Osunkoya AO, Komolafe EO, Malomo AO, Shokunbi MT, et al. Pattern of fatal head injuries in Ibadan--a 10 year review. Med Sci Law 2002:42;160-6.

18. Akinpelu OV, Oladele AO, Amusa YB, Ogundipe OK, Adeolu AA, Komolafe EO. Review of road traffic accident admissions in a Nigerian tertiary hospital. East Central Afr J Surg 2006;12:63-7.

How to cite this article: Adeolu AA, Rabiu TB, Orhorhoro OI, Malomo AO, Shokunbi MT. Relationship between injury severity, random blood glucose and management outcome in a cohort of Nigerian patients with head injury. J Neurosci Rural Pract 2015;6:216-20.

Source of Support: Nil. Conflict of Interest: The authors declare no conflict of interest. 